\title{
Is 'n Christelike universiteit moontlik?
}

\author{
W.J. Ouweneel \\ Dept. Wetenskapsleer \\ Potchefstroomse Universiteit vir $\mathrm{CHO}$ \\ POTCHEFSTROOM
}

\begin{abstract}
The question regarding the nature of a truly Christian University is addressed in this article. It is argued that such a university should develop a clear-cut concept of Christian scholarship (in the widest sense of the term). ('hristian scholarship is not 'derived' from the Bible or from any theology, but founded in a radical Christian-philosophical view of reality and knowledge. A truly Christian university has the duty to work within and further develop such a (hristian-cosmological and Christian-epistemological paradigm, and to point oul and elaborate its relevance for the various sciences. If this is not done, scholars will, under the guise of the Christian faith, unconsciously assume presuppositions of either a secular-humanistic. or a scholastic, or a biblicistic-fiundamentalist nature. It is pointed out that the foundational questions concerning the various special sciences are necessarily of a philosophical nature. and that. If one wants to practise science on a Christian hasis, one's philosophical paradigm has to be fully attuned to one's Christian life and world view. For the time being, the author prefers the Reformational philosophy developed along the lines of Dooyeweerd. Vollenhoven, and Stoker, not because it is the best but because it is the only radical (hristian, encompassing cosmology and epistemology available. The author makes this choice fully aware of the fact that this philosophy is, like all scientific theories, nothing but a fallible and preliminary consiruct, and that Christian scholarship was not begun, or did not become possible, only with Dooyeweerd c.s. The necessity of a radical Christian philosophy is hased upon the presupposition that all human activity is founded in a ground-notif. and that the latter is necessarily of a religious nature.
\end{abstract}

\section{Inleidend}

Hierdie artikel handel oor ' $n$ vraag waaroor enige Clristelike universiteit in die besonder moet besin, naamlik: Kan daar iets wees soos 'n Cliristelike universiteit? Wat is die moontlikheid, die wenslikheid en die bestaansreg van 'n Christelike universitcit? Ek wil hierdie vrae bespreek vanuit die vraag na die bestaansreg van die Potchefstroomse Universiteit vir Christelike Hoër Onderwys 
Talle mense redeneer blykbaar dat ' $n$ Christelike universiteit ' $n$ universiteit is wat deur Christene bestuur word, waar Christen-dosente onderrig gee en waar Christen-studente onderrig ontvang. Die gevaar is egter groot dat 'n dergelike universiteit in die praktyk slegs beteken dat die Christen-dosente aan daardie Christelike universiteit vir Christen-studente niks anders as die gangbare humanistiese wetenskap doseer nie. So ' $n$ universiteit is vir die jong student dalk nog skadeliker as 'n openlik sekulêre universiteit, waar die student wat uit 'n Christelike gesin kom, ten minste nog weet wat hom te wagte is. Aan 'n sogenáámd Christelike universiteit sou hy of sy eintlik bedrieg word, want hy of sy sou verwag om Christelike onderrig te ontvang, maar sal in werklikheid slegs die gangbare humanistiese onderrig ontvang. Die onderrig sou weliswaar deur Christene gegee word, maar die inhoud sou tog humanisties wees.

Ek gebruik die woord humanisme in die breedste sin om te dui op 'n denkstroming wat, veral sedert die Renaissance en later Descartes, die mens en sy bekwaamhede in die middelpunt van die (teoretiese) denke plaas en God op die agtergrond daarvan, of selfs heeltemal buite die gesigsveld plaas. Hunanisme word aan die een kant bepaal deur die ideaal van die moderne outonome mens. Hierdie ideaal impliseer die vrye sedelike selfbepaling van die mens in absolute vryheid, dit wil sê sonder enige beperking van bo, en sonder die beperking van óf vroeëre denkers óf die kerk óf die Bybel. Aan die ander kant word humanisme bepaal deur die ideaal van die moderne (natuur)wetenskaplike denke - 'n denkstelsel wat die mens in staat stel on die werklikheid soewerein te beheers en God as Skepper en Onderhouer van die werklikheid na die agtergrond van sy denke te skuif. ${ }^{1}$ Hierdie 'humanisme' in die breedste sin omspan feitlik die hele Westerse denke sedert Descartes, Spinoza en Leibniz (die Europese vasteland) en John Locke (die Britse Eilande) en laat sy invloed tot vandag toe geld.

\section{Is Christelike wetenskap moontlik?}

Die ideaal van 'n Christelike universiteit kan nou nader verduidelik word: aan 'n Christelike universiteit word wetenskap gedoseer word wat nie in die huma-

1 Vir ' $n$ briljante analisc van dic wortels en geskiedenis van dic humanisticse denke kyk Dooyeweerd (1984:169-495; vgl. 1960 en 1963). Ek handhaaf hicrdic verwysing ondanks byvoorbeeld die argumentasie van Taylor (1989), wat betoog dat talle sogenaamde Christclike denklyne in dic sogenaamde humanisticse tradisic opgeneem is en onder hierdic vlag bly voortleef het. Hierdic argumentasie is ongetwyfeld juis, en is al vroeer deur dic reformatoriese wysbegeerte beredencer: dit raak egter nie dic beslissende punt nic. Dit is nie soseer Christelike teorieet wat tecnoor humanistiese teorieë staan nic, maar dit is dic voortcoreticse, sentraal-rcligicusc Christclike grondmotief wat lctterlik 'radikaal' tecnoor die humanistiese grondmotief staan 
nistiese denkwêreld wortel nie, maar in die Christelike denkwêreld. Kortom: dit is 'n universiteit waar Christelike wetenskap gedoseer word. Met hierdie uitgangspunt het ons die vraagstelling verskuif na die plek waar dit eintlik hoort, naamlik of Christelike wetenskap moontlik is en wat onder Christelike wetenskap verstaan moet word

'n Christelike wetenskap is nie ' $n$ wetenskap wat net 'Christelike verskynsels' bestudeer nie, want dan sou slegs die teologie ' $n$ 'Christelike wetenskap' genoem kon word. ' $n$ Christelike wetenskap is ook nie 'n wetenskap wat uit die Bybel 'afgelei' word nie, want die Bybel gebruik nie wetenskaplike taal nie, verskaf geen wetenskaplike modelle nie, los geen wetenskaplike probleem op nie, behandel geen teoretiese uitgangspunte vir wetenskapsbeoefening nie en praat selfs glad nie oor die verskynsel wetenskap soos ons dit ken nie. Ook is ' $n$ Christelike wetenskap nie 'n wetenskap wat sy empiriese materiaal noodwendig op 'n ander wyse versamel of eksperimente op ' $n$ ander wyse uitvoer as nie-Christene nie. Daar is geen verskil tussen die werkswyse van die Christen-chemikus en dié van die niegelowige chemikus wat langs mekaar in die laboratorium staan nie. ${ }^{2}$

Wat is Christelike wetenskap dan? Die ervaring leer dat as 'n Christen-wetenskaplike nie bewus genoeg is van die vooronderstellings van sy wetenskaplike denke nie, hy dan outomaties in die vaarwater van of ' $n$ skolastiese siening of ' $n$ fundamentalisties-biblisistiese siening of ' $n$ humanistiese siening van die wetenskap teregkom. 'n Egte Christen-wetenskaplike is iemand wat werklik erns maak met sy Christelike lewens- en wêreldbeskouing, ook in sy wetenskapsbeoefening. Daarom is dit vir 'n Christelike universiteit in ons gebroke wêreld van lewensbelang om grondig na te dink oor die grondslae en uitgangspunte van die wetenskap. Sodanige besinning oor die grondslae en uitgangspunte van die vakwetenskap is per definisie ' $n$ wysgerige aangeleentheid. Daar is goeie wetenskapsteoretiese redes vir hierdie bewering, maar ook 'n eenvoudige historiese rede. Hierdie historiese argument is die invloed van humanistiese filosofieë op die ontwikkeling van die wetenskap - 'n invloed wat in die laaste vier eeue oorweldigend was. Daarom moet ' $n$ Christelike universiteit homself teen hierdie humanistiese filosofieë beskerm deur indringend daaroor en oor sy eie wysgerige uitgangspunte te besin. In die praktyk blyk dit egter baie moeilik te wees, want juis dit wat vir die Christen-wetenskaplike eintlik 'n lewensnoodsaak is, naamlik wysgerige besimning, wek in die praktyk dikwels groot weersin op. Daar is mins-

2 Dic nic-Christen-chemikus sal miskien bepaalde eksperimente wil uitvoer waarmec dic Christen-chemikus uit morcle oonwegings glad nic saamstem nic. Hierdic oorwegings is egter 'n etiese kwessic, en nie 'n chemiese kwessic as sodanig nic. Dit is egter wel belangrik om op tc merk dat dic vrac rondom 'n Christclike wetenskap dikwels ongclukkig net tot eticse kwessies herlei word - eticse vrac wat met dic cic aard van dic betrokke vakwetenskappe as sodanig niks te doen het nic. 
tens vyf redes hoekom Christen-wetenskaplikes so 'n groot afkeer van die filosofie ontwikkel het dat hulle dikwels liefs glad nie van enige wysgerige besinning op hulle vakgebied wil weet nie.

Die eerste rede is die kompleksiteit van die wysgerige terminologie en die formulering van redenasies. Die wysgeer - ook die Christen-wysgeer - praat dikwels 'n taal wat die vakwetenskaplike soms nie verstaan nie, en wat hy ook as baie spekulatief en eintlik dikwels as volkome irrelevant ervaar. Die tweede rede is ' $n$ gebrek aan wysgerige opleiding en dikwels ook ' $n$ gebrek aan belangstelling in teoretiese diskussies oor grondvrae, veral by kollegas in die toegepaste wetenskappe. Ten derde is daar die vrees om te veel buite die grense van die eie vakgebied te tree. Hierdie vrees ontstaan dikwels by vakspesialiste - spesialisasie veroorsaak tog ook dat mense toenemend méér weet van 'n steeds kleiner vakgebied. Hierdie vrees geld ook vir wetenskaplikes wat miskien tegnies baie goed is, maar binne hul werkkring baie min met werklikheidsinsig te doen het. Vierdens bestaan daar ' $n$ vrees vir wysbegeerte wat gegrond is op die feit dat dit in die praktyk gewoonlik gaan om die heersende, humanisties gekleurde wysbegeerte - ' $\mathrm{n}$ wysgerige beklemtoning wat die Christen eerder wil vermy. Die gevolg is 'n volstruispolitiek, waar 'n mens liewer hoegenaamd nie met wysgerige sake besig wil wees nie.

Ten vyfde wil vakwetenskaplikes dikwels min met die wysbegeerte te doen hê vanweë die siening van die veronderstelde 'neutrale, objektiewe en onbevooroordeelde' karakter van die wetenskap - 'n siening waardeur 'n besinning oor uitgangspunte en vooronderstellings sogenaamd glad nie nodig is nie. Talle vakwetenskaplikes neem hoegenaamd nie kennis van die ontwikkelinge in die moderne wetenskapsleer nie, en bly daardeur in die praktyk gewoonlik onbewustelik vasgekeer in die verouderde logiese positivisme, met sy klem op die sogenaande 'objektiewe feite' en 'objektiewe metodes'. Vandag het wetenskapsteoretici oor die algemeen tot die insig gekom dat wetenskaplike navorsing altyd wortel in in voorwetenskaplike, voorteoretiese sensus communis, ideologie, "first order principles", 'n wetenskaplike paradigma of dissiplinêre matriks, "background assumptions", "world picture" of "global assumptions", "control beliefs", "life perspective" of "confessional vision", "Weltanschauung", of hoe dit ook al genoem mag word. ${ }^{3}$

Die konklusie wat Christen-wetenskaplikes hieruit trek, is om nie alle filosofie op naïewe wyse te vermy nie, net soos die hoë frekwensie gulsigheid en vraatsug by party mense ons nie moet weerhou om te eet nie. Inteendeel, slegs deur 'n gron-

3 Vgl. respektiewelik Gadamer (1960), Habermas (1967), Miller (1969), Kuhn (1970),

Gouldner (1971), Radnitzky (1974), Woltcrstorff (1976), Wolters (1985), Wisdom (1987). 
dige wysgerige besinning oor die grondslae en uitgangspunte van die vakwetenskaplike arbeid kan ons moontlik bewaar bly vir ' $n$ gevaarlike vermenging met sowel skolastiese en biblisistiese asook humanistiese elemente.

Die sentrale vraag wat na vore kom is watter soort wysgerige besinning ons verkies. As alle wetenskap, ook die wysbegeerte, in bepaalde voorteoretiese geloofsveronderstellings wortel, sal ons as Christen-wetenskaplikes die duidelike keuse vir ' $n$ Christelik-wysgerige besinning moet maak. Niks verdien die naam 'Christelike wetenskap' as dit ' $n$ wetenskap impliseer wat gegrond is op een of ander neutrale, algemeen-wysgerige (in die praktyk die heersende humanistiese) wysbegeerte nie. Daarmee het ons ons vraagstelling opnuut verskuif. Die vraag na die moontlikheid van ' $n$ Christelike universiteit het ons verskuif na die vraag na die moontlikheid van Christelike wetenskap, en die vraag na die moontlikheid van 'n Christelike vakwetenskap verskuif ons nou weer na die vraag na die moontlikheid van 'n Christelike wyshegeerte.

\section{Die implikasie van die vraag 'Wat is fisika?'}

Voordat in besonderhede ingegaan word op die prinsipiële vraag insake $n$ Christelike wysbegeerte, wil ek eers die betekenis van ons onderwerp, met behulp van 'n eenvoudige voorbeeld probeer verduidelik. Dit is my oortuiging dat alle wetenskapsbeoefening van nature 'n wysgerige nadenke oor sy uitgangspunte vereis. 'n Mens hoef maar net byvoorbeeld vir 'n fisikus die eenvoudige vraag te vra wat fisika eintlik $i s$, of an 'n bioloog die vraag wat biologie eintlik is. Dit is duidelik dat hierdie vraag onmiddellik ander vrae veronderstel, soos byvoorbeeld in watter opsig fisika of biologie wetenskap is. Verder kan gevra word waarin fisiese en biologiese kennis van ons praktiese kennis van die natuur verskil. So ook kan die volgende vrae gevra word: Waarin verskil 'n fisiese uitspraak van ' $n$ biologiese uitspraak, of 'n biologiese uitspraak van 'n farmaseutiese uitspraak? Is biologiese uitsprake dalk net ' $n$ besondere vorm van chemiese uitsprake, en indien nie, waarom? In watter natuurbeskouing is ons natuurwetenskaplike uitsprake begrond?

Hierdie vrae is nie vakwetenskaplike vrae nie, maar wysgerige vrae. Tog wil vakwetenskaplikes dit dikwels nie insien nie. Hulle erken nie graag dat 'n fisikus as sodanig nie kan weet wat fisika eintlik is nie. Vakwetenskaplikes beweer dan dat hulle eie vakwetenskap niks van die filosowe kan leer aangaande eie uitgangspunte en metodes nie, en dat hulle vakgebied hom nie hoef te verantwoord teenoor die filosofie nie. Veral teoloe is op hierdie punt gewoonlik baie sensitief (vgl. byvoorbeeld Barth, 1932:6-9; Althaus, 1952:12; Heyns, 1977:16-17). Hierdie houding is te verstane, en elke vorm van pan-filosofisme, dit wil sê van deurdringing en oorheersing deur die wysbegeerte, moet inderdaad veroordeel word. 
Die wysbegeerte mag nooit die terreine van die verskillende vakwetenskappe as sodanig betree nie: wysgere moet nooit teoloë of fisici probeer wees nie

Dit is egter presies waar die probleem lê: die probleem is of die definisies van chemie of biologie en hulle posisiebepaling binne die geheel van die vakwetenskappe inderdaad chemiese of biologiese kwessies is, en of die wysbegeerte, as dit hierdie vrae probeer beantwoord, inderdaad buite sy eie terrein tree. Ek glo nie dat dit die geval is nie. Hoewel die fisika byvoorbeeld talle sake bestudeer, ondersoek dit nie die probleem wat onder wetenskap in die algemeen en onder die wetenskap van die fisika in die besonder verstaan moet word nie. Hierdie vrae behoort nie tot sy navorsingsprojek nie en is nie toeganklik vir sy metode nie. Sodra die fisikus nadink oor sy taak as sodanig, versaak hy sy eintlike taak, naamlik om fisiese verskynsels te bestudeer. En sodra hy sy eintlike taak weer hervat, los hy sy bespiegelings oor hierdie taak, anders sou hy nie in staat wees om hierdie taak na behore uit te voer nie. Die feit dat selfs die vakwetenskaplike af en toe met hierdie sogenaamde voorvrae besig is, maak hierdie voorvrae nooit 'n deel van sy vakwetenskaplike taak as sodanig nie. Die bioloog bestudeer biotiese verskynsels; die vakfilosoof bestudeer die bioloog se aktiwiteit. ${ }^{4}$ Die plante en diere of die fisiologiese prosesse wat die bioloog bestudeer, sê vir hom nie wat biologie is, of wat die spesifieke kenmerke van die biologie is en waarin dit van die fisika verskil nie. Plante en diere lewer wel antwoorde op biologiese probleme, maar nie die antwoord op enige wysgerige of wetenskapsteoretiese probleem nic.

Dit gaan egter in die wysbegeerte nie net om die wetenskapleer nie - ook byvoorbeeld die wysgerige antropologie speel 'n wesenlike rol. Ons hoef maar net te

4 Op hierdie punt het reformatoriesc denkers veral met betrekking tot dic tcologie klem gelê onder andere Popma (1946). Dooyewecrd (1958:15; 1960) betoog dat nie 'n bepaalde vakwetenskap self nie, maar net dic Christelike wysbegecrte, gelei deur die sentrale Bybelse grondmotief, die ensiklopediese plek van hierdic vakwetenskap saam met die ander vakwetenskappe kan identifiseer. "The reason is that special sciences do not reflect on their special viewpoint as such" (Dooyeweerd, 1960:127); "theology [cn enige ander vakwetenskap - WJOl cannot give us a philosophical total view of the mutual relation and coherence between the different aspects of our experience within the temporal order" (ibid,, 133; cf. 152,154). Dooyeweerd stel dat hierdie identifikasie van dic plek van die tcologie of enige ander vakwetenskap bepaal word deur ' $n$ kritiese analise van dic modale struktuur van die betrokke werklikheidsaspek en sy plek binne die geheel van die empiriese werklikheid. Vir enige vakwetenskap moet dic insig in sy struktuur ' $n$ vooronderstelling wees vir die afbakening van sy wetenskaplike standpunt. Hierdie vooronderstelling is egter van wysgerige aard omdat dit dic teoretiese totaliteitsiening van modale strukture van die empiriese werklikheid impliseer - 'n totaliteitsiening wat net vir die wysbegecrte kenmerkend is. Geen enkcle vakwetenskap as sodanig kan ons insig gee in dic modale struktuur en aard van die betrokke modale aspek nic. maar moct hierdic insig ontlecn aan dic betrokke vakfilosofie 
dink aan die feit dat elke vakwetenskaplike en wysgerige besinning 'n menslike denkaktiwiteit is. 'n Dergelike denkakt het sy eie logiese struktuur maar sodra ons nadink oor hierdie logiese struktuur van die denkakt, het ons buite die kring van die feitelike vakwetenskap getree. En selfs hierdie logiese besinning is onvoldoende; die logiese struktuur van die denkakt veronderstel naamlik self weer ' $n$ bepaalde teoretiese siening van die mens as gehéél. Wat is die verhouding tussen die menslike denke en die ander aspekte van ons menswees? Wat van die ou sekulêre siening van die mens dat hy ' $n$ by uitstek rasionele wese is en die wesenlik onchristelike siening van die sogenaamde outonomie van die rede? Selfs hierdie vrae is nie omvattend genoeg nie. ' $n$ Wysgerige antropologie het self weer sy eie noukeurig omskrewe plek binne die geheel van 'n samehangende, omvattende wysgerige siening van die werklikheid: 'n wysgerige kosmologie

Slegs binne die raanwerk van 'n wysgerige werklikheidsbeskouing kan enige vakwetenskap sinvol beoefen word, met ander woorde 'n wysgerige werklikheidsbeeld is 'n transendentale voorwaarde vir die beoefening van die vakwetenskappe. Die wysgerige werklikheidsbeeld onderlê dus vakwetenskaplike besinning en maak dit eers moontlik. Ek sou hierdie stelling met talle kennisteoretiese argumente kon ondersteun, maar selfs daarsonder kan die noodwendigheid en onvermydelikheid van 'n wysgerige werklikheidsbeskouing vir die vakwetenskappe maklik ingesien word. Gedurende die afgelope eeue het elke teologiese, elke sielkundige en elke natuurwetenskaplike siening byvoorbeeld aangeleun op die teoretiese werklikheidsbeskouings van bepaalde humanisties-wysgerige strominge.

\section{Is Christelike wysbegeerte moontlik?}

Die wesenlike punt is daarom nie of enige vakwetenskap sonder 'n wysgerige werklikheidsbeskouing kan werk nie - want oor die antwoord kan daar geen twyfel wees nie - maar die wesenlike vraag is wat die wortels is van die wysgerige werklikheidsbeskouing wat die vakwetenskap ten grondslag lê. Op hierdie vraag, kan drie verkeerde aannames gestel word.

* Ten eerste kan hierdie werklikheidsbeskouing nie uit die Bybel 'afgelei' word nie, want soos reeds gestel, gee die Bybel geen antwoord op enige wetenskaplike of filosofiese probleem as sodanig nie. Op geen enkele wyse kan 'n rasioneel-teoretiese werklikheidsbeeld direk aan ons pre-rasionele, pre-teoretiese Skrifgeloof 'ontleen' word nie. Dit beteken egter nie dat die Bybel vir ons wysgerige werklikheidsbeskouing geen betekenis het nie. Inteendeel, die Skrif verskaf die basis vir ons (pre-rasionele, pre-teoretiese) Christelike geloof, en hierdie geloof onderlè ons Christelike (rasionele, maar pre-teoretiese) wêreldbeskouing. In hierdie wêreldbeskouing wortel ons rasioneel-teoreties-wysgerige werklikheidsbeskouing, wat die vrug is van 
selfstandige teoretiese navorsing, al word dit altyd deur die Skrifgetroue grondmotief geinspireer. Hierdie 'grondmotief' is die religieuse dryfkrag op die bodem van ons bestaan - ' $n$ religieuse dryfkrag wat deur die Heilige Gees in ons hart gewerk word. Deur middel van hierdie grondmotief deurstraal die Skrif ook ons wysgerig-teoretiese navorsing.

* Ten tweede kan die vakwetenskappe 'n Christelike werklikheidsbeskouing ook nie ontleen aan die teologie nie, hoewel dit steeds baie voorkom. Ook aan die PU vir $\mathrm{CHO}$ kom dit nog voor dat vakwetenskaplikes wat wil nadink oor die Christelike grondslae van hulle vak, die hulp van 'n teoloog inroep. Hierdie benaderingswyse was ook 'n groot fout wat die Vrije Universiteit in Amsterdam in die begin van sy bestaan gemaak het: dit wou die wetenskap begrond in die sogenaamde 'gereformeerde beginsels', wat in die teologiese fakulteit vir die ander fakulteite uitgewerk moes word. Hierdie misverstand gaan terug op die ou skolastiese verdeling van die wetenskap, waarby die teologie hom sou besighou met die 'bo-verdieping' van die genade, die geestelike lewe, God, die Bybel, ensovoorts, terwyl die ander wetenskappe (sowel die wysbegeerte as die vakwetenskappe) hulle besig hou met die 'onderverdieping' van die natuur, die empiriese werklikheid, die liggaamlike en psigiese, ensovoorts. Die teologie as sodanig is glad nie toegerus om die vakfilosofiese probleme van enige vakwetenskap op te los nie - die teologie het genoeg met sy eie vakfilosofiese voorvrae te doen. Ook aan die Vrije Universiteit het dit nie gewerk nie; die teologiese fakulteit was nie vir hierdie taak toegerus nie, met die gevolg dat die ander fakulteite spoedig hulle eie pad, dit wil sê 'n hoofsaaklik humanistiese pad gevolg het. In plaas daarvan moes hulle op die basis van 'n Christelik-wysgerige paradigma hulle eie skeppingsordinansies uitgewerk en gepositiveer het: natuurwette in die Christelike natuurwetenskappe, ekonomiese nonne in die Christelike ekonomie, juridiese norme in die Christelike regswetenskap, ensovoorts.

Ons kan die wysbegeerte definieer as die teoretiese analise van die Bybelse idee van die skeppingsorde of die wetsorde wat God vir die geskape werklikheid ingestel het; en die verskillende vakwetenskappe kan ons definieer as die pogings om die verskillende betrokke skeppingsordinansies te positiveer. Die Godgegewe konstante struktuurbeginsels van getal, ruimtelikheid, beweging, energie en organiese lewe vorm die transendentale, aprioriese voorwaarde vir die geskape werklikheid en ook vir die natuurwetenskappe. Sonder hierdie struktuurbeginsels is natuurwetenskappe nie eers moontlik nie. Daar bestaan geen egte natuurwetenskap waarin nie op een of ander manier aan hierdie struktuurbeginsels 'n konkrete teoretiese vorm gegee is nie, hoe gebrekkig ook al. Dit is nie die teologie nie, maar 'n Christelike wysbegeerte wat ons kan help om hierdie natuurwetenskaplike 
navorsing raak te sien as ' $n$ positivering van natuur-beginsels, wat hulle begin in God se skeppingswoord vind (vgl. Troost, 1969:21).

Hierdie uitgangspunt beteken egter ook nie dat die teologie geen betekenis vir ons Christelik-wysgerige werklikheidsbeeld het nie. Die teologie het onder andere die taak om ons pre-teoretiese Skrifgeloof voortdurend te verhelder en te verdiep. Daarom kan die teologie dikwels ' $n$ nuttige rol speel in die wyse waarop ons Skrifgeloof deurwerk in ons Christelike wêreldbeskouing en vandaar in ons Christelik-wysgerige werklikheidsbeskouing. Dit is byvoorbeeld die teologie wat die aard van die talle skeppingsordinansies kan uitwys, naamlik as openbaring van die veelsydigheid en rykdom van God se skepperswil. Maar dit is die verskillende vakwetenskappe self wat, vanuit 'n Christelik-wysgerige werklikheidsperspektief, die verskillende skeppingsordinansies moet uitwerk (Troost, 1978: 117). In 'n sekere sin is hulle taak ook niks anders as dit nie.

* Ten derde kan die vakwetenskappe die werklikheidsbeskouing wat nagestreef word ook nie ontleen aan die gangbare wysgerige tradisie nie, omdat dit soos reeds gestel, in amper al sy fasette basies humanisties is. Hierdie humanistiese tradisie is daarom op die vlak van sy religieuse grondmotief vreemd aan die Christelike wetenskapsbeoefening, wat in die Skrif gegtond wil wees. Dit beteken egter nie dat die humanistiese wysbegeerte volkome nutteloos is nie. Inteendeel, elke wetenskaplike ondememing, in watter afvallige ultimate commitment dit ook al gegrond mag wees, bevat belangrike waarheidsmomente. Die 'opdringerige' aard van die werklikheid deurstraal selfs die donkerste filosofieë en ander denkrigtings. Waarheidsmomente is egter geen verontskuldiging on die humanistiese (voorteoretiese, ten diepste sentraal-religieuse) denkraam oor te neem waarin sulke waarheidsmomente opgesluit lê nie. As ons dit gaan doen, kan ons die ideaal van 'n Christelike wetenskap vergeet, en daarmee ook die ideaal van 'n Christelike universiteit.

Vir 'n Christen-wetenskaplike sien ek daarom net een moontlike manier om vir homself die noodwendige teoreties-wysgerige werklikheidsbeskouing te verskaf 'n werklikheidsbeskouing wat sy vakwetenskap vanuit 'n Christelike perspektief onderlê en op hierdie wyse 'n waarlik Christelike universiteit moontlik maak. Wat ons nodig het, is 'n wysgerige werklikheidsbeskouing wat gegrond is in die Bybelse grondmotief. en nie in enige skolastiese of humanistiese grondmotief 
nie. ${ }^{5}$ Alle teoretiese denke funksioneer uiteindelik vanuit die perspektief van 'n bepaalde teoreties-wysgerige werklikheidsbeskouing. Sodanige beskouing is op die diepste vlak altyd noodwendig in die greep van 'n bepaalde voorteoretiese (Bybelse of nie-Bybelse) grondmotief of basiese dryfkrag of ultimate commitment. In ons ideaal van 'n Christelike universiteit beoefen ons 'n wetenskap wat gegrond is in 'n Christelik-wysgerige werklikheidsbeskouing. Hierdie werklikheidsbeskouing mag Christelik genoem word omdat die hart van die wysgeer in die greep is van die Skrifgetroue grondınotief, en omdat hierdie grondmotief van daaruit sy hele kosmologiese denkarbeid deurstraal. In hierdie voorteoretiese grondmotief word vervolgens 'n teoreties-wysgerige grondidee of paradigma of dissiplinêre matriks gegrond (Strauss, 1991:10)6, van waaruit dan 'n wysgerige kosmologie of werklikheidsleer opgebou kan word.

Die feit dat ons hier uitgaan van die skerp antitese in die werklikheid tussen lig en duisternis, tussen die Gees van God en die gees van die Satan, tussen Skrifgetrouheid en Skrifontrou, beteken nie noodwendig dat 'n dergelike wysgerige aktiwiteit hom heeltemal op 'n eiland bevind nie. Dit is naamlik glad nie verbode dat 'n Skrifgetroue wysbegeerte byvoorbeeld konsepte gebruik wat (of ten minste, waarvan die teenswoordige betekenisse) tipies dié van ons eie tyd is nie. Hier word gedink aan konsepte soos byvoorbeeld subjek, geskiedenis, persoon (in die moderne sielkundige betekenis), beslissing, verantwoordelikheid, gemeenskap, $a k t$, ensovoort (vgl. Brunner, 1946:31), en selfs meer onlangse terme soos paradigma, commitment of metafoor. Ook die Skrifgetroue wysgeer of vakwetenskaplike is altyd kind van sy tyd. Sulke konsepte word verantwoord deurdat elke wysgerige stroming en ook elke vakwetenskap ontwikkel in wisselwerking met sy eie tydsperiode. Die groot verskil is egter dat elkeen van hierdie terne gedefinieer word, of moet word, in volle ooreenstemming met die Bybelse grondmotief van hierdie wysbegeerte of vakwetenskap

5 Wat Spykman (1988:149) sê met betrekking tot dic tcologic, geld vir enige vakwetenskap, naamlik dat dit "of one piece" moet wees met sy filosofiesc prolegomena, dit wil sê Christelike vakwetenskap moct begrond wecs in Christelike filosofic. Fowler (s.j.:9) sê ook tereg: "the theologian [en ook enige ander vakwetenskaplike - WJO] will not remain true to the faith he professes if the philosophical framework he adopts is not consistent with that faith".

6 Die gangbare terminologie in hierdie opsig is taamlik veclvoudig en verwarrend. In elk geval moet dic nic- (of voor-) teoretiese en dic wetenskaplike werklikhcidsienings van mekaar onderskei word. Self onderskei ek tussen (a) dic bo-rasioncle, voortcoreticsc grondmoticf (dic fides qua; kyk voctnoot 7), (b) dic rasioneel geartikulcerde, voortcoreticse wêreldbeskouing, en (c) die rasionele, teoretiesc (wysgerige) paradigma. Wat dic wêreldbeskouing betref praat Wolters (1985:2) van "lifc perspective" of "confessional vision", terwyl hy daaraan herinner dat Marxiste van 'n "ideologie" en dic sekulêre sosiale wetenskappe waarskynlik van 'n "system of values" sou praat. 


\section{Die eise vir 'n Christelike wysbegeerte}

Vervolgens gaan daar gepoog word om 'n voorstelling te vorm van die voorwaardes waaraan 'n Christelik-teoreties-wysgerige denkraamwerk vir die vakwetenskappe aan 'n Christelike universiteit moet voldoen. Ons het al kortliks aangestip dat 'n vakwetenskap wat Skrifgetrou wil wees, noodwendig 'n wysgerige werklikheidsbeskouing veronderstel wat in dieselfde Bybelse grondmotief as hierdie vakwetenskap gefundeer is. Die vraag is egter waar 'n wysbegeerte te vind is wat gegrond is in 'n Bybelse (of noukeuriger - 'n Bybelgetroue) wêreldbeskouing.

Persoonlik kies ek in hoofsaak die refonnatoriese wysbegeerte wat deur Dooyeweerd, Vollenhoven en Stoker ontwikkel is. 'n Dergelike keuse is egter glad nie vanselfsprekend nie, ook nie binne 'n Christelike universiteit nie. Miskien kan die vraag gestel word of 'n sprong van die besinning oor ' $n$ Christelike filosofie na die konkrete keuse van die Wysbegeerte van die Wetsidee nie te maklik gemaak word nie. ${ }^{7}$ Moet 'n mens, om van 'n Christelike universiteit te kan praat, eers oorgehaal word tot Dooyeweerd se filosofie? Is dit werklik die Christelike filosofie? Partymaal word gevra waarom ons Dooyweerd kies en nie byvoorbeeld die Suid-Afrikaanse filosowe H.G. Stoker of J.A.L. Taljaard of D.F.M. Strauss of die Amerikaanse filosowe N. Wolterstorff of A. Plantinga se Christelik-filosofiese kosmologieë nie. En illustreer die verskille tussen hierdie filosofieë nie dat blykbaar nie een van hulle ' $n$ presiese en korrekte beskrywing van die werklikheid is nie?

Hierdie vrae is belangrik en te begrype, maar dit lyk vir my asof die antwoorde daarop nie moeilik is nie.

7 Ek verwys hicr na J. Botha (1991:209-213) se reaksic op my uitdaging (Ouwenecl, 1991) met betrekking tot 'n samchangende Christclik-ıysgerige werklikhcidsicning. Verskillende vergissings wat hy myns insiens maak (soos sy suggesties dat ek Dooyeweerd se filosofic as die Christelike werklikheidslecr sou beskou. en dat ck sou ontken dat Dooyeweerd se model maar net 'n konstruksic van 'n kensubjck is, en dat ck hicrdic filosofic sou gclykstel aan 'dic werklikheid') word in dic teks bespreck. Botha suggereer ook dat hy volgens my 'oorgchaal' sou moet word tot Dooyeweerd om 'n 'direkte tocgang' te kry tot die werklikheid soos gegec in dic prakticse kenhouding. Ook dit is 'n vergissing. Ek het nooit gesuggereer dat 'n mens cers Dooyeweerd se teoricë moct aanvaar om in prakticse kenhouding te kan aanncem nic: dan moes Adam Dooycwecrd reeds in dic paradys geken het. Dic feit dat Botha hierdie siening by my vermoed, is kennelik 'n gevolg van dic sekulêre taalspel waarin hyself gesosialisecr is. Tot hicrdic taalspel behoort onder andere dic bedenklike verteoretiscring van dic prakticse denke. Aan dic ander kant kan insig in Dooycweerd se denke wel help om 'n gocie tcoretiese siening van die praktiese kenhouding te ontwikkel. 
* In die eerste plek moet opgemerk word dat ek nooit sou wou suggereer dat die reformatoriese wysbegeerte die enigste of die beste Christelike werklikheidsbeskouing vorm nie. Die reformatoriese wysbegeerte is slegs een moontlike konstruksie van die teoretiese kensubjek; daarom is hierdie model nie sonder meer identies met die 'werklikheid' of selfs met 'die Christelike werklikheidsbeskouing' nie. Dit is juis 'n basiese insig dat teorieë - en dit sluit ook die reformatoriese wysbegeerte in - nie aan die werklikheid 'ontleen' of daaruit 'afgelees' word nie. Vakwetenskaplike en wysgerige teorieë is altyd vrye skeppinge van die menslike gees (vgl. Popper, 1972:192), en dit geld ook vir die reformatoriese wysbegeerte. Teorieë beoog sekerlik om 'n weergawe van die feite van die werklikheid te gee - teorieë is 'geïntendeerde waarheid' - maar hulle is nooit 'identies' met die werklikheid, of selfs 'n 'kopie' of 'spieëlbeeld' van die werklikheid nie. Wat ek egter wel glo, is dat die reformatoriese wysbegeerte weliswaar nie noodwendig die beste Christelike wysbegeerte is nie, maar vir sover ek weet eenvoudig die enigste omvattende en samehangende radikaal-Christelike werklikheidsbeskouing is wat op die oomblik beskikbaar is.

* Dit bring my direk by die tweede punt. Ons moet nie die verskille tussen die onderskeie Christen-wysgere misbruik on van die verantwoordelikheid te ontkom om 'n Bybelgetroue werklikheidsbeskouing te aanvaar nie. Radikaal-Christelike wysgere is in werklikheid glad nie so verdeeld nie. Die reformatoriese wysbegeerte is die skool van sowel Dooyeweerd as Vollenhoven; hulle verskille is van sekondêre belang. H.G. Stoker van die PU vir $\mathrm{CHO}$ is nog altyd beskou as 'n geesverwante denker, wat langs dieselfde lyne grondliggende gedagtes ontwikkel het (Verburg, 1989:192, 195). Taljaard is 'n geesverwante leerling van Stoker en Vollenhoven, en Strauss is 'n geesverwante leerling van Dooyeweerd. Geeneen van hulle het sy eie, onafhanklike Christelik-wysgerige skool probeer stig nie. Inteendeel, luulle het langs die parallelle lyne van Dooyeweerd, Vollenhoven en Stoker gewerk

Die vraag kan gestel word of Wolterstorff en Plantinga sulke onafhanklike Christelik-wysgerige skole daargestel het - skole wat samehangende, omvattende werklikheidsteorieë daarstel. Die antwoord is: Nee. In die Verenigde State verteenwoordig hulle voortreflike voorbeelde van die talle Christen-wysgere wat geskool is in taalanalise, of in etiek, of in estetiek, of in godsdiensfilosofie. Hulle bied egter nie 'n omvattende werklikheidsleer (ontologie) of selfs kennisleer (epistemologie) wat wortel in die Bybelse grondmotief nie. Vir sover ek weet, streef hulle ook hoegenaand nie daama nie. 'n Omvattende ontologie en epistemologie word volgens my beste wete net in die Dooyeweerd-VollenhovenStoker tradisie gevind. 
Op hierdie punt moet die drie misverstande vermy word. Ten eerste impliseer hierdie keuse vir die reformatoriese wysbegeerte nie dat eers ná hierdie keuse die ontwikkeling van enige vakwetenskap op 'n Skrifgetroue basis moontlik is nie. Soos Dooyeweerd dit self stel (1958:72), sou so 'n bewering belaglik wees. ' $n$ Waarlik Skrifgetroue beoefening van die vakwetenskappe en die wysbegeerte is onmiddellik moontlik sodra die sentrale grondmotief van die goddelike Woordopenbaring - 'n grondmotief wat beslis nie wysgerig (en trouens ook nie teologies of andersins vakwetenskaplik of teoreties) is nie - ernstig geneem word. Die Skrifgetroue beoefening van die wetenskap moet konsekwent sy uitgangspunt in hierdie grondmotief kies, en nie in die antieke, die skolastiese, die biblisistiese of die humanistiese denke nie. As 'n wetenskapsbeoefening die goddelike woordopenbaring as grondmotief kies, sal dit vanself langs die Skriftuurlike lyne beweeg en implisiet wysgerige insigte toepas wat deur hierdie grondmotief geïnspireer is. Dit sal die geval wees selfs as hierdie insigte nog nie deurdink en sistematies en samehangend in 'n Skrifgetroue wysbegeerte uitgewerk is nie Wanneer sodanige insigte egter reeds gesistematiseer is, hou dit natuurlik groot voordele in en kan 'n afwyking van die Skrifgetroue grondmotief meer geslaag voorkom word.

Die tweede misverstand is dat gedink word dat die insig in die noodsaak van ' $n$ waarlik Christelike wysbegeerte en vakwetenskapsbeoefening wat in die Bybelse grondmotief wortel, eers met Dooyeweerd, Vollenhoven en Stoker begin het. Miskien was hierdie insig selfs nooit geheel sonder aanhangers nie. Selfs reeds voor die Hervormers, wat beslis insig in die Bybelse grondinotief gehad het, sou ons byvoorbeeld aan die Middeleeuse teoloog en filosoof Bonaventura kon dink. Hy praat van die lumen cognitionis sensitivae (die lig van die sintuiglike kennis) en die lumen cognitionis philosophiae (die lig van die wysgerige kennis), wat die transendente voorwaardes van die betrokke wetenskappe vorm. Uiteindelik herlei hy hierdie lumina (ligte) tot die een lumen superius scripturae (hoër lig van die Skrif), en daarmee tot die stem van Christus, die vleesgeworde Woord van God (Quaracci, 1883; aangehaal deur Schlink, 1983:25,26). Hierdie soort insigte kom reeds lank voor die ontwikkeling van die refornatoriese wysbegeerte voor en moet dus as sodanig geëvalueer word. Aan die ander kant is dit duidelik dat die vakwetenskappe geweldig verryk kan word $a s$ 'n samehangende Skrifgetroue wysbegeerte konkreet opgebou en uitgewerk en aan die vakwetenskappe ten grondslag gelê word.

Die derde misverstand is dat as ons vir die reformatoriese wysbegeerte kies, ons onsself geweldig sou beperk en daardeur die vakwetenskaplike arbeid op Christelike grondslag skade sou berokken. Ek glo egter nie dat hierdie moontlikheid die geval is nie om die eenvoudige rede dat alles in die reformatoriese wysbegeerte oop is vir kritiek, verbetering, vervanging en uitwerking, hehalwe op een besliste fundamentele punt. 'n Mens sou die hele refornatoriese filosofie op 
grond van deeglike argumente mag verwerp, maar na my mening kan die Bybelse grondmotief nie prysgegee word sonder om die vakwetenskappe in die arms van die skolastiek of die humanistiese denke te dryf nie. Wat beklemtoon moet word, is dat watter wysgerige werklikheidsbeskouing die Christen-wetenskaplike hier ook al mag verkies, dit een moet wees wat radikaal gefundeer is in die Bybelse grondmotief. Anders gesê: as die Christelike wetenskapsbeoefening in die Bybelse grondmotief gegrond wil wees, dan het dit 'n teoreties-wysgerige werklikheidsbeskouing nodig wat in dieselfde Bybelse grondmotief gegrond is.

\section{Is Christelike vakwetenskappe moontlik?}

Dit is miskien makliker om oor Christelike wysbegeerte te praat as oor Christelike vakwetenskappe. In die wysbegeerte gaan dit immers om teoretiese grondvrae waarin 'n Christelike standpunt baie makliker aan die orde gestel kan word. In die vakwetenskappe gaan dit egter om navorsings en eksperimente waarin 'n Christelike standpunt gewoonlik glad nie (eksplisiet) aan die orde kom nie sekerlik nie in die natuurwetenskappe nie. Tog is dit vir 'n Christelike universiteit van wesenlike belang om die vraag te stel of iets soos 'Christelike wetenskap' moontlik is - nie net op die vlak van die wysbegeerte nie, maar ook veral op die vlak van die vakwetenskappe. Ek herhaal daarom my vraag: Is 'n Christelike vakwetenskap werklik moontlik? Die Suid-Afrikaanse wysgeer Johann Mouton het 'n paar jaar gelede (1989a) hierdie vraag negatief beantwoord in 'n bespreking van 'n publikasie van die $\mathrm{PU}$ vir $\mathrm{CHO}$ oor 'n Clristelike perspektief op paradigmas in die wetenskappe. Sy kritiek is beantwoord deur een van die redakteurs van hierdie publikasie, Elaine Botha (1989; vgl. Mouton se repliek, 1989b). Ek kan in hierdie artikel natuurlik nie 'n uitvoerige verdediging bied van die idee van 'n Christelike wetenskap, wat ook 'n Clristelike wysbegeerte insluit nie; daarom sal ek my beperk tot enkele stellings, waarin ek my standpunt saamvat.

* Ten eerste is elke mens, en nie in die laaste plek die wetenskaplike nie, in sy of haar diepste eksistensiële wese gerig op die lewensvraag wat die absolute Oorsprong en onderhoudende Grond van sy of haar bestaan en van die hele empiriese werklikheid is. Elke mens het 'n diep eksistensiële behoefte aan hierdie houvas. Hierdie gerigtheid is daarom 'n egte gedrewenheid, en daarom praat ons dikwels van 'n grondmoticf, 'n basiese, stuwende krag, wat die mens beheers tot in die diepste van sy hart. Die mens oriënteer sy hele eksistensie ten opsigte van hierdie ware of venneende Oorsprong en Grond. Die spreekwyse dat ons gedryf word na ons Oorsprong en Grond, is 'n wysgerige manier om religie te omskryf (Dooyeweerd, 1984:57); daarom praat ons van 'n 'religieuse grondmotief'. Hierdie 'religieuse grondmotief' word deur sommige mense die ultimate commitment, die 'diepste verbintenis' van elke menslike wese genoem. Religie is ten diepste, soos Berkhof 
(1985:6) dit beskryf het, "die relasie tot die Absolute". Die werklik ultimate commitment is daarom noodwendig 'religieus', en elke mens is daarom ook noodwendig 'religieus'. Dit is eenvoudig soos God hom gemaak het - die mens kan nie lewe sonder hierdie 'religieuse dryfkrag' nie

* Ten tweede moet ons opmerk dat hierdie religieuse dryfkrag nie by alle mense basies gelyk is nie. Die religieuse grondmotief kan anastaties wees, dit wil sê in die greep van die Woordopenbaring betreffende God, Christus, die sondeval, die verlossing, die voleinding, ensovoorts. Die religieuse grondmotief kan ook apostaties wees, dit wil sê in die greep van bepaalde heidense of gemengde idees waarin die Woordopenbaring nie ten volle geëer word nie, of selfs heeltemal verwerp word. ${ }^{8}$ Anders gesê: basies is daar maar net twee grondmotiewe: Skrifgetrou of Skrifontrou, dit wil sê die mens het homself of verbind tot die Bybelse selfgetuienis as die geïnspireerde, gesaghebbende, betroubare en geloofwaardige Woord van God, of die mens het homself nie daartoe verbind nie. Op hierdie punt het ons met die diep antitese te doen waarop Abraham Kuyper reeds so groot klem gelê het: nie maar net die teenstelling tussen wedergeborenes en niewedergeborenes nie, maar, vanweë die sondige natuur wat ons nog het, die teenstelling tussen die vlees en die Gees wat dwarsdeur ons eie hart en bestaan loop.

* In die derde plek: hierdie religieuse grondmotief kleur, deurdring, bepaal vorm 'n transendentale voorwaarde vir ons basiese uitgangspunte, geloofsvooronderstellings, wêreldbeskouing, of hoe dit ook genoem mag word. Hier lê die kruks van die siening wat ek verteenwoordig: word ons wêreldbeskouing inderdaad beheers deur ons religieuse grondmotief? Ek antwoord dat ek nie kan insien hoe my diepste geloofsopvattings oor skepping, sondeval, verlossing en voleinding - wat rasionele eksplikasies van my pre-rasionele grondmotief is - iets anders sou kon doen as om my opvattings oor die werklikheid, die lewelose en die lewende natuur, die kultuur, die geskiedenis, die mens ensovoorts grondig te bepaal nie. Enige rasionele siening van al hierdie verskillende fasette van ons wêreld kan nie anders as om radikaal (d.i. tot in die radix = wortel van ons bestaan) beheers te word deur ons pre-rasionele grondmotief nie. Die verstand van die mens is nie outonoom nie, maar word beheers deur die mens se pre-rasionele geloof. Hoe sou ek immers enersyds die mens se eindigheid kon bely, dus ook die eindigheid van sy rede, en aan die anderkant die rede as outonoom kon sien? Die rede word a priori eksistensieel beheers en bepaal deur dit wat hierdie eindigheid

8 Vanweë die sonde kan geen mens op aarde natuurlik volkome in oorecnstemming met die Woordopenbaring wees nic; ck praat slegs van dic grondinstelling en -neiging van die mens se hart 
transendeer: die geloof, waarin die mens pre- of supra-rasioneel sy eie rasionaliteit kan verantwoord, ja, waarin hy in alle opsigte sy laaste grond en sekerheid vind.

* In die vierde plek: die genoemde 'basiese uitgangspunte', 'geloofsvooronderstellings' of 'wêreldbeskouing' is as sodanig pre-teoreties van aard en moet noukeurig van teoreties-wetenskaplike paradigmas of dissiplinêre matrikse onderskei word. Dit word in die wetenskapsleer tans taamlik algemeen aanvaar dat hierdie teoretiese paradigmas rus in sulke preteoretiese grondveronderstellings of geloofsopvattings. As hierdie pre-teoretiese grondveronderstellings self weer rus in ons religieuse grondmotief of 'diepste verbintenis', dan is daarmee ook aangetoon dat ons wetenskaplike paradigmas self ook uiteindelik rus in ons religieuse grondmotief of 'diepste verbintenis'. Paradigmas word nie net deur sosiale, ekonomiese, estetiese, perseptiewe en sensitiewe faktore, of selfs deur 'godsdienstige' faktore bepaal nie, maar ten diepste deur religieuse faktore - beter gesê: die religieuse dryfkrag - wat ons hele tydelik-funksionele lewe volstrek transendeer. (Godsdienstige faktore daarenteë word hier gesien as net een van die talle verskillende aspekte van ons tydelike bestaan. $)^{9}$

* In die vyfde plek: alle vakwetenskaplike aktiwiteit vind plaas binne die raamwerk van sulke teoreties-wetenskaplike paradigmas. Ook dit word vandag in die wetenskapsleer blykbaar taamlik algemeen aanvaar. Die vernaamste verskil tussen die konsensus in die wetenskapsleer en die reformatories-wysgerige siening is die sentrale en basiese plek wat in hierdie laaste siening toegeken word aan religieuse verbintenis. Ek is vas oortuig dat nie net alle vakwetenskaplike aktiwiteite binne die raamwerk van een of ander paradigma plaasvind nie, maar ook dat alle paradigmas uiteindelik gegrond is in ' $n$ mens se religieuse verbintenis. As hierdie afleiding korrek is, kan ons die volgende konklusie nie meer vermy nie: alle wetenskaplike aktiwiteit word uiteindelik bepaal deur ' $n$ mens se religieuse verbintenis. In hierdie eenvoudige, maar fundamentele stelling lê myns insiens die regverdiging vir die bestaan van 'n Christelike universiteit.

Hierdie stelling kan nader verduidelik word deur terug te keer tot die vraag: Is Christelike vakwetenskapsbeoefening hoegenaand moontlik? Ons kan hierdie vraag op hierdie stadium soos volg herformuleer: Is vakwetenskapsbeoefening wat gegrond is in 'n paradigma wat deurtrek is en beheers word deur die Skrif-

9 In die reformatoriese wysbegcerte praat ons van dic pistiese of geloofs-aspek, wat ook een van die modale synswyses van die temporele werklikheid is en baie duidelik onderskei moct word van konkretc geloofs-opvartings (fides quae) en van geloof in dic sentraal-religicuse sin: fides qua. 
getroue religieuse grondmotief moontlik of wenslik? Dit sou interessant wees om te weet hoe Christen-denkers soos Mouton, wat aan hierdie moontlikheid of wenslikheid twyfel, hierdie vraag sou beantwoord met betrekking tot die teologie. Sulke denkers sou vermoedelik aarsel om die moontlikheid of wenslikheid van ' $n$ Christelike teologie in twyfel te trek. Tog sou dit konsekwent wees as hulle die moontlikheid of wenslikheid van 'n Christelike wetenskap in die algeméén in twyfel trek. As 'n Skrifgetroue teologie volgens hulle siening moontlik en noodwendig is, lyk dit moeilik om die konklusie te vermy dat ook ' $n$ Skrifgetroue wysbegeerte en wetenskap in die algemeen moontlik en noodwendig is. En as hulle omgekeerd hierdie laaste moontlikheid ontken of betwyfel, lyk dit moeilik om die konklusie te vernny dat dan ook 'n Skrifgetroue teologie nie moontlik of noodwendig is nie, tensy ' $n$ mens uitgaan van die skolastiese onderskeid tussen die teologie (wat tenggaan op openbaring) en die ander wetenskappe (wat teruggaan op die 'lig van die natuurlike rede').

Die sentrale vraag is myns insiens hoe ons die een of die ander konklusie kan verantwoord. Voordat ons dit egter probeer verantwoord, is 'n ander oorweging myns insiens nog baie interessanter: dit is dat ' $n$ wetenskapsteoretiese verantwoording - hoe dit ook al mag uitsien - self altyd onvermydelik plaasvind binne die raamwerk van 'n bepaalde (geartikuleerde of ongeartikuleerde) werklikheidsen kennisheskouing. Die denker wat beweer dat alle wetenskaplike aktiwiteit uiteindelik bepaal word deur ' $n$ mens se religieuse verbintenis, doen dit binne die raamwerk van sy werklikheids- en kennisbeskouing. En die denker wat ontken dat alle wetenskaplike aktiwiteit uiteindelik bepaal word deur 'n mens se religieuse verbintenis, doen dit ewe-eens binne die raamwerk van sy werklikheids- en kennisbeskouing. 'n Teorie oor die moontlikheid of onmoontlikheid van Christelike teorieë veronderstel 'n siening van teorieë in die algemeen, binne die raamwerk van een of ander epistemologie, wat self deel uitmaak van een of ander kosmologie - 'n kosmologie wat Christelik of nie-Christelik is. Hierdie gedagte bring ons by ' $n$ belangrike punt. As bepaalde Christen-denkers gelyk het, word ons wetenskapsbeoefening nie noodwendig deur ons 'diepste verbintenis' (wat anastaties of apostaties is) beheers nie. Dit beteken dat dit moontlik sou wees om 'n deel van ons lewe, naamlik ons wetenskapsbeoefening, van hierdie 'diepste verbintenis' te skei. Dit beteken weer dat nie ons hele lewe onder die beslag van ons Christelike geloof en van die Skrif lê nie; en dit beteken ten slotte ten diepste 'n loëning van die reformatoriese grondstelling dat die hele lewe van 'n mens bepaal word deur van sy geloof of ongeloof. Sulke Christen-denkers plaas hulself met hulle loëning van 'n Cluristelike wetenskap uiteindelik buite die reformatoriese tradisie.

As dit omgekeerde egter wél waar is, naamlik dat enige wysgerige kosmologie (en daarmee ook ons wetenskaplike paradigmas en dus ons vakwetenskapsbeoefening) beheers word deur ons religieuse grondmotief, dan het dit ook ' $n$ 
interessante gevolg. Dit impliseer naamlik dat die vraag oor die moontlikheid van 'n Christelike wetenskap self onvermydelik behandel word binne 'n wysgerige denkraamwerk wat of Christelik of nie-Christelik is, dit wil sê basies anastaties of apostaties, Skrifgetrou of Skrifontrou. Blykbaar kan ons nooit ontkom aan 'n 'diepste verbintenis' wat of Skrifgetrou of Skrifontrou is nie. Selfs die teoretiese vraag of 'n Skrifgetroue wetenskap moontlik of noodwendig is, word myns insiens vanaf die begin bepaal deur iemand se voorteoretiese 'diepste verbintenis', wat óf Skrifgetrou óf Skrifontrou is.

\section{Konklusie}

'n Christelike universiteit is ' $\mathrm{n}$ universiteit waar nie net wetenskap deur Christene beoefen word nie, maar waar Christelike vakwetenskapsbeoefening plaasvind. Christelike wetenskap is nie wetenskap wat in 'n Christelike moraal of in 'n versameling Bybeltekste begrond is nie, is nie skolasties of biblisisties nie, maar is wetenskap wat rus in 'n Christelik-teoreties-wysgerige werklikheidsbeskouing. Sodanige teoretiese werklikheidsbeskouing rus self in 'n pre-teoretiese wêreldbeskouing, wat radikaal gevoed word deur die geloof van die Skrifte en hom bewustelik distansieer van enige humanistiese, skolastiese of fundamentalistiese invloed. Van watter Christelike wysbegeerte ons uitgaan, is nie belangrik nie, solank dit gaan om 'n werklik radikaal-Christelik-wysgerige werklikheidsbeskouing. Dit gaan nie om Dooyeweerd of enige ander Christen-denker nie, want hulle het almal slegs menslik-gebrekkige arbeid gelewer. Slegs die Skrif is volkome. Dit gaan daarom dat ons ons wetenskapsbeoefening steeds weer toets aan 'n Christelik-wysgerige werklikheidsbeskouing, dat ons hierdie werklikheidsbeskouing steeds weer toets aan ons pre-teoretiese wêreldbeskouing, en dat ons hierdie wêreldbeskouing steeds weer toets aan die Skrif - want In u lig sien ons die lig. 'n Christelike universiteit bestaan, en kan ook bly bestaan op grond van hierdie voortdurende worsteling om sy grondslae, sy uitgangspunte, sy wortels te toets.

\section{Bibliografie}

ALTHAUS, P. $1952^{3}$. Die christliche Wahrheit. Gütersloh : Bertelsmann. BARTH, K. 1932. Die kirchliche Dogmatik, 1/1. Zollikon-Zürich : Evangelischer Verlag. BERKHOF, H. $1985^{5}$. Christelijke geloof. Nijkerk : G.F. Callenbach.

BOTHA, J. 1991. Waarheidsteoriee en interpretasie. Koers, 56(2): 185-215.

BOTHA, M.E. 1989. Misplaaste kritiek? Koers, 54(3):359-381.

BRUNNER, E. 1946. Die christliche Lehre von Gott: Dogmatik, Bd.I. Zürich : ZwingliVerlag.

DOOYEWEERD, H. 1958. De verhouding tusssen wijsbegeerte en theologie en de strijd der faculteiten. Philosophia Reformata, 23:1-21, 49-84

DOOYEWEERD, H. 1960. In the Twilight of Western Thought: Studies in the Pretended Autonomy of Philosophical Thought. Philadelphia : Presbyterian and Reformed Publishing Company 
DOOYEWEERD, H. 1963. Vernieuwing en bezinning: Om het reformatorisch grondmotief. Zutphen : Van den Brink.

DOOYEWEERD, H. 1984 (repr.). A New Critique of Theoretical Thought, I: The Necessary Presuppositions of Philosophy. Jordan Station : Paideia Press.

FOWLER, S. s.j. What Is Theology? Blackburn : Foundation for Christian Scholarship.

GADAMER, H-G. 1960. Wahrheit und Methode: Grundzüge einer philosophischen Hermeneutik. Tübingen : Mohr.

GOULDNER, A. 1971. The Coming Crisis of Western Sociology. New York : Basic Books.

HABERMAS, J. 1972. Knowledge and Human Interests. Boston : Beacon.

HEYNS, J.A. 1977. Grondlyne van 'n algemene wetenskapsleer, en: Teologie as wetenskap. ( $m$ Heyns, J.A. \& Jonker, W.D., Op weg met die teologie. Pretoria : NG Kerkboekhandel. p. 13-228.)

KUHN, T.S. 1970. The Structure of Scientific Revolutions. Chicago : University of Chicago Press.

MILLER, J.F. 1969. Science and Religion: Their Logical Similarity. Religious Sirudies, 5:49. 68.

MOUTON, J. 1989a. Resensie van Paradigmas in die werenskappe: 'n Christelike perspektief. Koers, 54(1):122-134.

MOUTON, J. 1989b. Protesteer die dame nie te veel nie? Koers, 54(3):382-394

OUWENEEL, W.J. 1991. Korrespondensie of koherensie? Diskussie, veral na aanleiding van J. Botha: Semeion (1990). Koers, 56(2):167-184

POPMA, K.J. 1946. De plaats der theologie. Franeker: Wever.

POPPER, K.R. 1972. The Logic of Scientific Discovery. London: Hutchinson

RADNITZKY, G. 1974. Preconceptions in Research: A Study. Human Context, 6:1-63

SCHLINK, E. 1983. Oekumenische Dogmatik: Grundzüge. Göttingen : Vandenhoeck \& Ruprecht.

SPYKMAN, G.J. 1988. Christian Philosophy as Prolegomena to Reformed Dogmatics. (In Wethmar, C.J. \& Vos, C.J.A., 'n Woord op sy tyd: 'n Teologiese feesbundel aangebied aan Professor Johan Heyns ter herdenking van sy sestigste verjaarsdag. Pretoria : NG Kerkboekhandel. p. 137-155.)

STRAUSS, D.F.M. 1991. Wat is teologie? Tydskrif vir ('hristelike Welenskap, 27(2):1-22.

TAYLOR, Ch. 1989. Sources of the Self: The Making of the Modern Identity. Cambridge, Mass. : Harvard University Press.

TROOST, A. 1969. De openbaring Gods en de maatschappelijke orde. Philosophia Reformata, 34:1-37.

TROOST, A. 1978. De relatie tussen scheppingsopenbaring en woordopenbaring Philosophia Reformata, 43:101-129.

VERBURG, M.E. 1989. Herman Dooyeweerd: Leven en werk van een Nederlands christenwijsgeer. Baarn: Ten Have.

WISDOM, J.O. 1987. Challengeability in Modern Science. Aldershot: Gower.

WOLTERS, A.M. 1985. Creation Regained: Biblical Basics for a Reformational Worldview. Grand Rapids : W B. Eerdmans.

WOLTERSTORFF, N. 1976. Reason Within the Bounds of Religion. Grand Rapids : W.B. Eerdmans 
